\title{
Efficient nitrogen and phosphorus removal from wastewater by screening and constructing a novel Chlorella sp.-Bacillus taeanensis SD148BN12 consortium
}

\section{Liping Liu}

Ocean University of China

\section{Mengyu Zhang}

Ocean University of China

yun Li ( $\nabla 15318790309 @ 163 . c o m$ )

Ocean University of China

\section{Luqing Pan}

Ocean University of China

\section{Le Dou}

Ocean University of China

\section{Zhaopeng Su}

Ocean University of China

\section{Research Article}

Keywords: microalgae-bacteria consortium, nitrogen removal, phosphorus removal, biomass production, wastewater treatment, Chlorella sp., Bacillus taeanensis

Posted Date: February 3rd, 2022

DOl: https://doi.org/10.21203/rs.3.rs-1270593/v1

License: @ (i) This work is licensed under a Creative Commons Attribution 4.0 International License. Read Full License 


\section{Abstract}

The discharge of wastewater rich in nitrogen and phosphorus were posing a serious threat to ecological balance and human health. In the study, Bacillus taeanensis SD148BN12 with biosafety and capability of aerobic nitrogen removal by assimilation was selected to construct the Chlorella sp.-Bacillus taeanensis SD148BN12 consortium (M-B). Compared with single axenic Chlorella sp. and single Bacillus taeanensis SD148BN12, M-B improved the removal efficiencies of total nitrogen (91.89\%) and total phosphorus (94.58\%), the biomass yield $(0.52 \mathrm{~g} / \mathrm{L})$, as well as the contents of carbohydrate and lipid after cultivation in synthetic wastewater. M-B had the high and stable nitrogen removal efficiency at temperature $20-30{ }^{\circ} \mathrm{C}$, salinity $20-40 \%$, light intensity 50-200 $\mu \mathrm{mol}$ photons $\mathrm{m}^{-2} \mathrm{~s}^{-1}, \mathrm{pH}$ 6-9, C/N ratio 1-10, N/P ratio 4-20, $\mathrm{N}$ concentration 1-50 mg/L. The conspicuous removal efficiency of nitrogen and phosphorus from actual marine wastewater could be realized by M-B. Meanwhile, the synergistic interaction between Chlorella sp. and strain SD148BN12 was demonstrated by the characteristics of cell growth, photosynthetic activity and material exchange. The study provided an economical and environmentally friendly strategy for efficient removal of nitrogen and phosphorus from wastewater (including the neglected aquaculture wastewater) by establishing a hopeful microalgaebacteria consortium.

\section{Introduction}

Excessive nitrogen $(\mathrm{N})$ and phosphorus $(\mathrm{P})$ contents in water environment have become a worldwide problem, resulting in eutrophication, impacting the ecological balance (Mohsenpour et al. 2021) and finally threatening human health. In addition to the discharge of industrial wastewater and domestic sewage, without enough attention, intensive aquaculture was also a main reason for the increase of $\mathrm{N}$ and $\mathrm{P}$ contents in water environment (Yang et al. 2017). In intensive aquaculture system, only a small fraction of the feeds was converted to the biomass of aquatic animals, of which only about $25 \%$ of $\mathrm{N}$ and $\mathrm{P}$ were utilized (Zhang et al. 2020b). Inorganic N (especially ammonia and nitrite with the toxicity to animals) and P from residual feed and animal waste released and accumulated in the water, which leaded to water quality deterioration and aquatic animal disease (Mohsenpour et al. 2021). After a production cycle, the aquaculture wastewater was often discharged into adjacent water without proper treatment, exacerbating a series of water quality problems (Malibari et al. 2018, Mohsenpour et al. 2021). Therefore, it was urgent to optimize and popularize the technologies of $\mathrm{N}$ and $\mathrm{P}$ removal from wastewater, of which, biological treatment have become an attractive choice due to the low cost, high efficiency and less secondary pollution (Hou et al. 2021).

Bacteria were the conventional basis in the biological treatment of wastewater. Recently, the bacteria with capability of heterotrophic nitrification-aerobic denitrification (HNAD), by which ammonium $\left(\mathrm{NH}_{4}{ }^{+} \mathrm{N}\right)$, nitrite $\left(\mathrm{NO}_{2}{ }^{-} \mathrm{N}\right)$, and nitrate $\left(\mathrm{NO}_{3}{ }^{-} \mathrm{N}\right)$ were mainly converted to gas and removed, have been largely applied to wastewater treatment under aerobic conditions (Zhao et al. 2019). However, the $\mathrm{N}$ removal processes of HNAD could cause the loss of $\mathrm{N}$ and the production of greenhouse gas such as $\mathrm{N}_{2} \mathrm{O}$ (Zhang et al. 2020a). Studies have shown that some bacteria removed inorganic $N$ mainly by assimilating $N$ into cells, avoiding $N$ loss and harmful intermediate accumulation. A study showed that the Pseudomonas putida Y-9 was able to remove 99.36\% of $\mathrm{NH}_{4}{ }^{+}-\mathrm{N}$ and $82.00 \%$ of $\mathrm{NO}_{3}{ }^{-}-\mathrm{N}$ and the above $\mathrm{N}$ sources were mainly absorbed by the bacteria through assimilation rather than lost as gas (Huang et al. 2021b). Marine bacterium Vibrio sp. Y1-5 were able to achieve $\mathrm{N}$ removal efficiency as good as HNAD through assimilation, with no risk of detrimental intermediate ( $L i$ 
et al. 2017). Nonetheless, there were rare reports on the efficient assimilation in wastewater treatment. In addition, most of bacteria with $\mathrm{N}$ removal capability were isolated from industrial or domestic sewage, and such bacteria might not function safely and stably in the aerobic aquaculture environment with high salinity and relatively low $\mathrm{N}$ concentration (Su et al. 2021). In consequence, the acquisition of efficient and safe in-situ bacteria removing $\mathrm{N}$ by assimilation would provide a novel, reliable and environmentally friendly strategy for removal of $\mathrm{N}$ in wastewater and pollution control of $\mathrm{N}$ in aquaculture.

Microalgae with the capability of $\mathrm{N}$ and $\mathrm{P}$ removal was another common organism used in wastewater treatment (Su 2021), making up for the deficiency of inefficient $P$ removal for most bacteria with $\mathrm{N}$ removal capability. Studies on microalgae-bacteria consortia revealed a mass of interactions between the two microorganisms. Material exchange was considered as one of the main interactions of microalgae-bacteria consortia: the aerobic bacteria consumed $\mathrm{O}_{2}$, decomposed organic matter, produced $\mathrm{CO}_{2}$ and released growth hormone, vitamins or other microalgal growth factors; the microalgae assimilated inorganic N, $\mathrm{P}$ and $\mathrm{CO}_{2}$ to synthesize biomass, in addition, released $\mathrm{O}_{2}$ and extracellular organic matter (Ferro et al. 2019, Saravanan et al. 2021). Based on the above synergistic relationship, some of microalgae-bacteria consortia as effective water purification system achieved the simultaneous removal of $\mathrm{N}$ and $\mathrm{P}$ and the production of microalgae biomass. Compared with traditional treatment using single microalgae or single bacteria, microalgae-bacteria consortia could adapt to more complex environments and achieve higher removal efficiency of $\mathrm{N}$ and $\mathrm{P}$, as well as biomass yield (Saravanan et al. 2021). According a study about the treatment of dairy-derived liquid digestate, the removal efficiency of $\mathrm{N}, \mathrm{P}$ and the growth rate of microalgae in co-culture system of Chlorella vulgaris and activated sludge were higher than that in single Chlorella vulgaris system (Feng et al. 2020). Another study showed that Chlorella sp. improved the removal efficiency of total phosphorus to $98.78 \%$ and had a higher biomass yield by culture with wastewater-borne bacteria (Liu et al. 2017a). Many studies like above showed that the consortiums constructed by mixing bacteria and microalgae had excellent performance of wastewater treatment, but the consortiums might be uncontrollable in actual application due to the complex biological composition (Wang et al. 2020). Therefore, relevant studies began to focus on the combinations of individual microalgae and individual strain to ensure the stability of the symbiotic consortiums, explore the mechanisms of efficient synergy and improve the benefits of wastewater treatment (Ji et al. 2018). However, there were few studies on screening specific bacteria and constructing a stable microalgae-bacteria consortium to efficient $\mathrm{N}$ and $\mathrm{P}$ removal and biomass production in wastewater, let alone reports on aquaculture wastewater with high salinity (Li et al. 2018). Filling the gaps would provide a new insight for resourceful treatment of wastewater.

In the study, the Bacillus taeanensis SD148BN12 isolated from aquaculture ponds and the Chlorella sp. were screened to construct a new microalgae-bacteria consortium that could improve $\mathrm{N}$ and $\mathrm{P}$ removal efficiency and biomass yield effectively. The biosafety and aerobic N removal capability of strain SD148BN12 were identified. The respective function and interactions of strain SD148BN12 and Chlorella sp. in M-B was explored and the effect of environmental factors on the $\mathrm{N}$ removal efficiency of M-B were assessed. The application of M-B to remove $\mathrm{N}$ and $\mathrm{P}$ in mariculture water and mariculture wastewater showed good results. The study provided a potential view for combining in-situ bacteria and microalgae to remove N, $P$ and recover resource simultaneously from wastewater. Furthermore, it provided a reference for the environmentally-friendly treatment of aquaculture wastewater.

\section{Materials And Methods}




\subsection{Microalgae, bacteria and media}

The microalgae species Chlorella sp. (Chlorella sp. strain MACC/C95) was provided by the Laboratory of Applied Microalgae Biology, Ocean University of China, China and cultured in f/2 medium (Lananan et al. 2014). The light intensity, temperature and light/dark cycle were controlled at $50 \mu \mathrm{mol}$ photons $\mathrm{m}^{-2} \mathrm{~s}^{-1}, 25^{\circ} \mathrm{C}$ and 12 $h / 12 h$, respectively.

In order to obtain an axenic isolate of Chlorella sp., $100 \mathrm{mg} / \mathrm{L}$ of each of the following antibiotics were administered: ampicillin, streptomycin, kanamycin sulfate and gentamycin sulfate. The Chlorella sp. was inoculated in the $\mathrm{f} / 2$ medium containing mixed antibiotics at a ratio of $10 \%$ for 5 days and then transferred to the $f / 2$ medium without antibiotics for 8 days. After repeated twice, the Chlorella sp. culture was streaked on $f / 2$ agar plates to obtain single microalgal strains. Then the isolates were transferred into the $f / 2$ liquid medium without antibiotics for further culture and the Chlorella sp. culture was coated on LB agar plates and cultured at $28^{\circ} \mathrm{C}$ for one week. Non-contamination was demonstrated by the absence of bacteria on the LB agar plates. The axenic Chlorella sp. strains were stored in $\mathrm{f} / 2$ medium and sub-cultured every 14 days for all subsequent experiments.

The 36 strains with the capability of $\mathrm{N}$ removal were preserved by the Laboratory of Environmental Physiology of Aquatic Animals, Ocean University of China, China. These strains were respectively isolated from Litopenaeus vannamei ponds located in Shandong, Guangdong and Hainan Province, and stored at $-80{ }^{\circ} \mathrm{C}$ in $25 \%$ glycerol solution. The 36 strains cultured at $\mathrm{C} / \mathrm{N}=10, \mathrm{~N}$ concentration $=10 \mathrm{mg} / \mathrm{L}, 28^{\circ} \mathrm{C}$ and $160 \mathrm{rpm}$, could remove more than $50 \%$ of $\mathrm{NH}_{4} \mathbb{}-\mathrm{N}$ in $48 \mathrm{~h}$. Before experiments, the bacteria were cultured in LB medium at 28 ${ }^{\circ} \mathrm{C}, 160 \mathrm{rpm}$ for $24 \mathrm{~h}$.

The heterotrophic nitrification medium (HNM), denitrification media (DM) and simultaneous nitrification and denitrification medium (SNDM) were used to measure the capability to $\mathrm{N}$ removal of strain SD48BN12. The HNM contained (per liter): glucose $0.25 \mathrm{~g},\left(\mathrm{NH}_{4}\right)_{2} \mathrm{SO}_{4} 0.0471 \mathrm{~g}, \mathrm{~K}_{2} \mathrm{HPO}_{4} \cdot 3 \mathrm{H}_{2} \mathrm{O} 0.05 \mathrm{~g}, \mathrm{FePO}_{4} \cdot 4 \mathrm{H}_{2} \mathrm{O} 0.01 \mathrm{~g}$, $\mathrm{MgSO}_{4} \cdot 7 \mathrm{H}_{2} \mathrm{O} 0.25 \mathrm{~g}$. The DM based on the HNM replaced $\left(\mathrm{NH}_{4}\right)_{2} \mathrm{SO}_{4}$ with $\mathrm{NaNO}_{3} 0.493 \mathrm{~g}(\mathrm{DM}-1), \mathrm{KNO}_{3} 0.0722$ $\mathrm{g}$ (DM-2), respectively. The SNDM based on the HNM increased glucose to $0.75 \mathrm{~g}$ and replaced $\left(\mathrm{NH}_{4}\right)_{2} \mathrm{SO}_{4}$ with $3 \mathrm{~N}$ sources: $\left(\mathrm{NH}_{4}\right)_{2} \mathrm{SO}_{4} 0.0471 \mathrm{~g}, \mathrm{NaNO}_{3} 0.493 \mathrm{~g}$ and $\mathrm{KNO}_{3} 0.0722 \mathrm{~g}$.

A synthetic wastewater medium (SWM) containing $\mathrm{NH}_{4}{ }^{\square}-\mathrm{N}, \mathrm{NO}_{2}{ }^{\square}-\mathrm{N}^{-} \mathrm{NO}_{3}{ }^{\square}-\mathrm{N}$ was used to cultivate microalgaebacteria consortiums. The SWM contained (per liter): glucose $0.25 \mathrm{~g}, \mathrm{NH}_{4} \mathrm{Cl} 0.0382 \mathrm{~g}, \mathrm{NaNO}_{2} 0.0246 \mathrm{~g}, \mathrm{NaNO}_{3}$ $0.0304 \mathrm{~g}, \mathrm{NaH}_{2} \mathrm{PO}_{4} \cdot 2 \mathrm{H}_{2} \mathrm{O} 0.0101 \mathrm{~g}, \mathrm{MgSO}_{4} .7 \mathrm{H}_{2} \mathrm{O} 0.25 \mathrm{~g}$. In addition, $1 \mathrm{~mL}$ of trace metal solutions were added to $1000 \mathrm{~mL}$ of the above solution: $\mathrm{FeCl}_{3} .6 \mathrm{H}_{2} \mathrm{O} 3.15 \mathrm{~g} / \mathrm{L}, \mathrm{Na}_{2}$ EDTA $4.36 \mathrm{~g} / \mathrm{L}, \mathrm{MnCl}_{2} .4 \mathrm{H}_{2} \mathrm{O} 0.18 \mathrm{~g} / \mathrm{L}, \mathrm{ZnSO}_{4} .7 \mathrm{H}_{2} \mathrm{O}$ $0.022 \mathrm{~g} / \mathrm{L}, \mathrm{CoCl}_{2} \cdot 6 \mathrm{H}_{2} \mathrm{O} 0.01 \mathrm{~g} / \mathrm{L}, \mathrm{CuSO}_{4} .5 \mathrm{H}_{2} \mathrm{O} 0.0098 \mathrm{~g} / \mathrm{L}, \mathrm{Na}_{2} \mathrm{MoO}_{4} \cdot 2 \mathrm{H}_{2} \mathrm{O} 0.0063 \mathrm{~g} / \mathrm{L}$. All the HNM, DM, SNDM and SWM were prepared with filtered seawater (salinity $\approx 30 \%$ o, $\mathrm{pH} \approx 8.1$, total nitrogen $<0.01 \mathrm{mg} / \mathrm{L}$ ), adjusted the initial $\mathrm{pH}$ to 7.5 , and autoclaved before using.

\subsection{Screening of the strains co-cultured with Chlorella sp.}

In the experiment, 36 strains with $\mathrm{N}$ removal capability were co-cultured with Chlorella sp.. The microalgaebacteria consortiums with higher removal performance of $\mathrm{N}$ were screened by measuring the $\mathrm{N}$ removal efficiency of the microalgae-bacteria combinations. Chlorella sp. cultured for 8 days and strains cultured for 24 
h were washed and resuspended with aseptic SWM, adjusted the cell density, and added into $250 \mathrm{~mL}$ conical flasks containing $100 \mathrm{~mL}$ SWM. The initial cell densities of Chlorella sp. and strains in SWM were $5 \times 10^{5}$ cell/mL and $5 \times 10^{5} \mathrm{CFU} / \mathrm{mL}$, respectively. The culture system with only Chlorella sp. was applied to compare, and all the culture systems were incubated at $50 \mu \mathrm{mol}$ photons $\mathrm{m}^{-2} \mathrm{~s}^{-1}, 25^{\circ} \mathrm{C}, 140 \mathrm{rpm}$, under a $12 \mathrm{~h} / 12 \mathrm{~h}$ light/dark cycle for 8 days. The samples were taken from each flask to determine the contents of $\mathrm{NH}_{4}{ }^{+}-\mathrm{N}^{-} \mathrm{NO}_{2}{ }^{-}$ $\mathrm{N}$ and cell density periodically.

\subsection{Identification, biosafety assessment and $\mathrm{N}$ removal performance of strain SD148BN12}

The strain of Bacillus taeanensis SD148BN12 (Genbank accession number: MN988751.1) was selected by the co-cultivation of microalgae and bacteria for subsequent experiments (Huang et al. 2020a). Strain SD148BN12 was isolated from the water simples in mariculture ponds of Litopenaeus vannaei located in Dongying, Shandong Province and carried out genetic identification in the previous research for the Laboratory of Environmental Physiology of Aquatic Animals. The 16S rRNA gene sequence of strain SD148BN12 was compared with the reported gene sequences in GenBank database by Basic Local Alignment Search Tool (BLAST). A phylogenetic tree was constructed on MAGE 7.0 software with the neighbor-joining method. Morphological, physiological-biochemical characteristics and of the strain were also determined (Zhang et al. 2021a).

Strain SD148BN12 was inoculated on the agar plate with 5\% goat blood (Qingdao Hope Bio-Technology Co., LTD, China), and the hemolytic activity of the strain was determined by observing the existent of the hemolytic circle. In order to measure the antibiotic sensitivity of strain SD148BN12, according to European Committee on Antimicrobial Susceptibility Testing (EUCAST) disk diffusion method, the strain was coated on Mueller-Hinton agar plates and the antimicrobial susceptibility disk (Hangzhou microbial reagent co. LTD, Hangzhou, China) was placed on the surface of the mediums, then the diameter of the inhibition zone was determined after incubation.

After $24 \mathrm{~h}$ culture, $15 \mathrm{~mL}$ bacterial culture of strain SD148BN12 was obtained, centrifuged and removed supernatant, washed with the same amount of sterile filtered seawater, and the strains were resuspended. The bacterial suspension was severally transferred into $100 \mathrm{~mL}$ HNM, DM-1, DM-2, SNDM placed in $250 \mathrm{~mL}$ conical flasks at $1 \%(\mathrm{v} / \mathrm{v})$ ratio. All the flasks were continuously oscillating cultured at $160 \mathrm{rpm}$ with the temperature of $28{ }^{\circ} \mathrm{C}$ for $48 \mathrm{~h}$. The samples were withdrawn every $4 \mathrm{~h}$ and the cell density $\left(\mathrm{OD}_{600}\right)$ as well as the content of $\mathrm{NH}_{4}^{\square}-\mathrm{N}, \mathrm{NO}_{2}^{\square}-\mathrm{N}, \mathrm{NO}_{3}^{\square}-\mathrm{N}$, intracellular nitrogen (Intracellular $\mathrm{N}$ ) and total nitrogen (TN) were measured.

\subsection{Evaluation of M-B for N, P removal performance}

The Chlorella sp. cultured for 8 days and the Bacillus taeanensis SD148BN12 cultured for 24 h were washed and resuspended with aseptic filtered seawater, adjusted the cell density, and added into $250 \mathrm{~mL}$ conical flasks containing $100 \mathrm{~mL}$ SWM synchronously to form the M-B. Both of the Chlorella sp. (cell/mL) and strain SD148BN12 (CFU/mL) were at initial cell density of $5 \times 10^{5}$. Incubator parameters were set as temperature of 25 ${ }^{\circ} \mathrm{C}$, light intensity of $50 \mu \mathrm{mol}$ photons $\mathrm{m}^{-2} \mathrm{~s}^{-1}$, shaking speed of $140 \mathrm{rpm}$ and light/dark ratio of 12/12h. The culture system with same amount of Chlorella sp.-only (M-O) and the system with same amount of strain SD148BN12-only (B-O) were used to contrast. Samples were taken to analysis every 2 days. 
The following indicators were measured: the cell growth and biomass production parameters included the dry cell weight (DCW), the contents of protein, carbohydrate and lipid, the chlorophyll-a concentration and the number of viable bacteria; the photosynthetic activity parameter included the maximal photochemical efficiency $\left(\mathrm{Fv} / \mathrm{Fm}\right.$ ); the water quality parameters included the concentrations of $\mathrm{NH}_{4}{ }^{\mathrm{D}}-\mathrm{N}, \mathrm{NO}_{2}{ }^{\mathrm{D}}-\mathrm{N}, \mathrm{NO}_{3}{ }^{\mathrm{q}}-\mathrm{N}$, total nitrogen (TN), total phosphorus (TP) as well as the pH value and dissolved oxygen (DO) content.

\subsection{Effects of different factors on $\mathrm{N}$ removal efficiency of M-B}

The effects of factors including temperature, salinity, light intensity, $\mathrm{pH}$ value, $\mathrm{C} / \mathrm{N}$ ratio, N/P ratio, $\mathrm{N}$ content on the $\mathrm{N}$ removal capacity of $\mathrm{M}-\mathrm{B}$ were assessed by single-factor experiment. The basic conditions of the experiment were set as follows: Chlorella sp. after 8 days cultivation and strain SD148BN12 after $24 \mathrm{~h}$ cultivation were prepared into concentrated cell suspension with aseptic SWM, and added into $100 \mathrm{~mL}$ SWM served in $250 \mathrm{~mL}$ conical flasks simultaneously with the initial density of $5 \times 10^{5}$ cell $/ \mathrm{mL}$ (CFU/mL). The incubation conditions were set at $25^{\circ} \mathrm{C}, 50 \mu \mathrm{mol}$ photons $\mathrm{m}^{-2} \mathrm{~s}^{-1}, 140 \mathrm{rpm}, 12 \mathrm{~h}$ light/ $12 \mathrm{~h}$ dark with the salinity of $30 \%$, $\mathrm{pH}$ of $7.5, \mathrm{C} / \mathrm{N}$ ratio of $5, \mathrm{~N} / \mathrm{P}$ ratio of $10, \mathrm{~N}$ concentration of $20 \mathrm{mg} / \mathrm{L}$ and culture cycle of 8 days. The individual factor was adjusted according to the following designs: temperature was set at $15,20,25$, $30,35,40^{\circ} \mathrm{C}$; salinity was set as $0 \%, 10 \%, 20 \%$, $30 \%$, $40 \%$, $50 \%$ o (adjusted by the addition of $\mathrm{NaCl}$ and dilution with pure water); light intensity was set as $12.5,25,50,100,150,200 \mu \mathrm{mol}$ photons $\mathrm{m}^{-2} \mathrm{~s}^{-1}$; pH value was set as $6,7,7.5,8,8.5,9 ; \mathrm{C} / \mathrm{N}$ ratio was set as $0,1,2.5,5,10,15$ (the $\mathrm{N}$ concentration was stayed at $20 \mathrm{mg} / \mathrm{L}$ and the glucose content was changed); N/P ratio was set as 4, 5, 7, 10, 20, 40 (the $\mathrm{N}$ concentration was stayed at $20 \mathrm{mg} / \mathrm{L}$ and the $\mathrm{NaH}_{2} \mathrm{PO}_{4} \cdot 2 \mathrm{H}_{2} \mathrm{O}$ content was changed); $\mathrm{N}$ concentration was set as $1,2.5,5,10,20,50 \mathrm{mg} / \mathrm{L}$. The $\mathrm{M}-\mathrm{O}$ and $\mathrm{B}-\mathrm{O}$ with the same culture conditions were used to contrast.

\subsection{Real mariculture water and wastewater treatment by M-B}

The mariculture water (MW-1) was taken from the intensive Litopenaeus vannaei culture ponds. The physicochemical characteristics of MW- 1 were shown as follows: TN, $3.99 \pm 0.14 \mathrm{mg} / \mathrm{L} ; \mathrm{TP}, 0.70 \pm 0.01 \mathrm{mg} / \mathrm{L}$; $\mathrm{NH}_{4}{ }^{+}-\mathrm{N}, 2.08 \pm 0.08 \mathrm{mg} / \mathrm{L} ; \mathrm{NO}_{2}{ }^{-}-\mathrm{N}, 1.11 \pm 0.03 \mathrm{mg} / \mathrm{L}$; salinity, 30\%; $\mathrm{pH}, 7.78 \pm 0.11$. The mariculture wastewater (MW-2) were effluents of shrimp ponds. The physicochemical characteristics of MW-2 were shown as follows: TN, $13.10 \pm 0.19 \mathrm{mg} / \mathrm{L} ; \mathrm{TP}, 2.04 \pm 0.05 \mathrm{mg} / \mathrm{L} ;$ salinity, $30 \%$; $\mathrm{pH}, 7.81 \pm 0.13$. The Chlorella sp. suspension $\left(1 \times 10^{8} \mathrm{cell} / \mathrm{mL}\right)$ and strain SD148BN12 suspension $\left(1 \times 10^{8} \mathrm{CFU} / \mathrm{mL}\right)$ were simultaneously added into conical flasks containing $100 \mathrm{~mL} \mathrm{MW-1} \mathrm{and} \mathrm{conical} \mathrm{flasks} \mathrm{containing} 100 \mathrm{~mL} \mathrm{MW}-2$. The inoculated cell density ratios of Chlorella sp. (cell/mL)-to-strain SD148BN12 (CFU/mL) were set as $10^{4}: 10^{4}, 10^{5}: 10^{5}, 10^{6}: 10^{6}$. The culture systems were incubated at $25^{\circ} \mathrm{C}, 50 \mu \mathrm{mol}$ photons $\mathrm{m}^{-2} \mathrm{~s}^{-1}, 140 \mathrm{rpm}, 12 \mathrm{~h}$ light $/ 12 \mathrm{~h}$ dark. Samples were taken from each container to measure the concentrations of $\mathrm{N}$ and $\mathrm{P}$ in the water.

\subsection{Analytical methods}

\subsubsection{Determination of cell density}

Bacterial density was determined as follows: $\mathrm{OD}_{600}$ values were measured at $600 \mathrm{~nm}$ through a spectrophotometer. The McFarland turbidity of bacterial suspension was measured by bacterial nephelometer (TA-2XJ, Beijing, China). The number of viable bacteria was measured by the flat colony counting method. The microalgal density measurement used the hemocytometer method with an optical microscope. 


\subsubsection{Determination of biomass}

The biomass yields of B-O, M-O and M-B were indicated by DCW. The samples were filtered through a dry filter of $0.22 \mu \mathrm{m}$ pore size and dried at $105{ }^{\circ} \mathrm{C}$ to constant weight. DCW was expressed as the difference between the weight of the filter containing the sample after drying and the weight of the filter before using (Ji et al. 2018).

The biomass composition including protein, carbohydrate and lipid as well as chlorophyll-a in B-O, M-O and M-B were measured. The Biomass composition including protein, carbohydrate and lipid were extracted and quantified in accordance with the methods described by previous studies (Li et al. 2018): the protein content of the extracts was determined by Lowry's method (Lowry et al., 1951), with the bovine serum albumin as the standard, the carbohydrate content was measured by phenol sulfuric acid colorimetric method (Monsigny et al., 1988), using the glucose as the standard; the lipid content was determined by the methanol-chloroform method (Bligh and Dyer, 1959). The chlorophyll-a was extracted by heating $90 \%$ methanol according to previous studies (Wang et al. 2020), and quantified absorbance by an ultraviolet spectrophotometer (UV-2000, Shanghai, China). With $90 \%$ methanol as a control, the chlorophyll-a concentration was calculated by the formula (Wang et al. 2019, Wang et al. 2020): Chlorophyll-a (mg/L) $=16.82 \times A_{665}-9.28 \times A_{652}$.

\subsubsection{Determination of photosynthetic activity}

The microalgal photosynthetic activity was indicated by Fv/Fm, which was measured by a modulated chlorophyll fluorometer (Junior-PAM, Heinz Walz GmbH, Effeltrich, Germany) and samples had a 20 min dark period in ambient conditions in the laboratory before determination (Wang et al. 2019).

\subsubsection{Determination of water quality}

The supernatant separated from simples after centrifuging at $4000 \times \mathrm{g}$ for $15 \mathrm{~min}$ at $4{ }^{\circ} \mathrm{C}$ was used to measure the concentrations of $\mathrm{NH}_{4}{ }^{\square}-\mathrm{N}, \mathrm{NO}_{2}{ }^{-}-\mathrm{N}, \mathrm{NO}_{3}{ }^{\square}-\mathrm{N}, \mathrm{TN}$ and TP by the standard method (Huang et al. 2017). The intracellular $\mathrm{N}$ content was the subtraction for TN of inoculated media and TN of inoculated media after centrifugation. The soluble organic $\mathrm{N}$ concentration in the solution was calculated by deleting $\mathrm{NH}_{4}{ }^{\mathrm{D}}-\mathrm{N}^{-} \mathrm{NO}_{2}{ }^{\mathrm{D}}-\mathrm{N}$, $\mathrm{NO}_{3}{ }^{\mathrm{D}}-\mathrm{N}$ from total soluble $\mathrm{N}$ at the end of cultivation (Huang et al. 2017). $\mathrm{N}$ or $\mathrm{P}$ removal efficiency was calculated as $\left(\mathrm{C}_{0}-\mathrm{C}_{1}\right) / \mathrm{C}_{0}{ }^{*} 100 \%\left(\mathrm{C}_{0}\right.$ : the initial concentration, $\mathrm{C}_{1}$ : the final concentration). The $\mathrm{pH}$ value and dissolved oxygen content of solution were measured by $\mathrm{pH}$ tester and dissolved oxygen tester.

\subsection{Statistical methods}

The non-seeded media were as controls and all the experiments were repeated three times. The date was expressed as means \pm standard deviations. One-way analysis of variance was used to analysis the differences among groups with SPSS 24.0. The $p<0.05$ meant the differences were significant statistically. Statistical analysis, calculation and drawing of experimental data were performed by Excel software.

\section{Results}

\subsection{Screening of the strain co-cultured with Chlorella sp.}

The 36 trains were co-cultured with the Chlorella sp. for screening combinations that could remove $\mathrm{N}$ from water rapidly (Fig. S1). The microalgae-bacteria consortiums cultured for 4 days were analyzed, and 10 groups of 
microalgae-bacteria consortiums more than $95 \%$ of $\mathrm{NH}_{4}{ }^{+}-\mathrm{N}$ removal efficiency were screened, in which the bacteria promoted or did not inhibit the growth of the Chlorella sp.. Groups of M-B12, M-B35 and M-B36 had higher $\mathrm{NO}_{2}{ }^{-}-\mathrm{N}$ removal efficiency and Chlorella sp. cell density, of which group M-B36 achieved the $\mathrm{NO}_{2}{ }^{-}-\mathrm{N}$ removal efficiency of $75.36 \%$ and Chlorella sp. density of $2.72 \times 10^{7}$ cell/mL respectively. After 8 days of culture, 5 groups of microalgae-bacteria consortiums had more than $95 \%$ of $\mathrm{NH}_{4}{ }^{+}-\mathrm{N}$ and $\mathrm{NO}_{2}{ }^{-}-\mathrm{N}_{\text {removal efficiency and }}$ higher Chlorella sp. density than M-O. In group M-B36, the removal efficiency of $\mathrm{NH}_{4}{ }^{+}-\mathrm{N}$ and $\mathrm{NO}_{2}{ }^{-}-\mathrm{N}$ were over $99 \%$, while the Chlorella sp. cell density $\left(5.52 \times 10^{7}\right.$ cell $\left./ \mathrm{mL}\right)$ was highest, and was 1.56 times as much as that of M-O. The strain SD148BN12 used in M-B36 was selected to construe a new microalgae-bacteria consortium.

\subsection{Identification, biosafety assessment and $\mathrm{N}$ removal performance of strain SD148BN12}

The strain SD148BN12 grew on LB agar plates as white, opaque, circular colonies with smooth surfaces and regular peripheries. Based on the results of the physiological and biochemical tests, strain SD148BN12 was positive for gram-staining, indole production, catalase activity, amylase activity, nitrate reductase activity, while negative for Voges-Proskauer (V-P) test, Methyl-Red (M.R) test, ammonia production test, gelatin liquefaction test and urease activity. The glucose oxidation fermentation test showed that the strain was fermentation type. The partial sequence analysis of the 16S rDNA of strain SD148BN12 revealed that the proximities of 16S rRNA between the strain SD148BN12 and Bacillus taeanensis strain BH030017 was 98.19\%. The phylogenetic tree further confirmed the homologies of strain SD148BN12 with some other phylogenetically related strains (Fig. 1). Therefore, the strain SD148BN12 was tentatively identified as Bacillus taeanensis SD148BN12.

During the culture process of strain SD148BN12 on the blood agar plate, hemolysis circle was not observed, suggesting that the strain had no hemolysis activity (Fig. S2). Antibiotic susceptibility was determined to characterize the resistance of bacterial strains. Of the 21 antibiotics tested (Table 1), the inhibition zone diameter of sulfisoxazole was $0 \mathrm{~mm}$, which indicated that the strain SD148BN12 was resistant to the drug. The strain showed high antagonism to streptomycin, gentamicin, erythromycin, ampicillin, bacitracin, ofloxacin, norfloxacin, ciprofloxacin, tetracycline with the inhibition zone diameter was less than $10 \mathrm{~mm}$. Beyond that, the strain had a high degree of sensitivity to the other 11 antibiotics.

The $\mathrm{N}$ removal performance and $\mathrm{N}$ balance of strain SD148BN12 cultured in different $\mathrm{N}$ sources medium for 48 h were shown in Fig. 2 and Table 2. In the $\mathrm{HNM}$, the $\mathrm{NH}_{4}{ }^{+}-\mathrm{N}$ concentration in solution decreased from 10.13 to $0.85 \mathrm{mg} / \mathrm{L}$, with nearly no accumulation of $\mathrm{NO}_{2}{ }^{-} \mathrm{N}$ and $0.30 \mathrm{mg} / \mathrm{L}$ accumulation of $\mathrm{NO}_{3}{ }^{-}-\mathrm{N}$. The maximum removal rate of $\mathrm{NH}_{4}{ }^{+}-\mathrm{N}$ was $1.13 \mathrm{mg} / \mathrm{L} / \mathrm{h}$. As well, in $\mathrm{DM}-1$, the concentration of $\mathrm{NO}_{2}{ }^{-}-\mathrm{N}^{-}$decreased from 10 to $1.13 \mathrm{mg} / \mathrm{L}$, with $0.56 \mathrm{mg} / \mathrm{L}$ accumulation of $\mathrm{NH}_{4}{ }^{+}-\mathrm{N}$ and $0.53 \mathrm{mg} / \mathrm{L}$ accumulation of $\mathrm{NO}_{3}{ }^{-}{ }^{-} \mathrm{N}$. The maximum removal rate of $\mathrm{NO}_{2}{ }^{-}-\mathrm{N}$ was $0.84 \mathrm{mg} / \mathrm{L} / \mathrm{h}$. In DM-2, the concentration of $\mathrm{NO}_{3}{ }^{-}-\mathrm{N}$ decreased from 10 to 1.15 $\mathrm{mg} / \mathrm{L}$, with nearly no accumulation of $\mathrm{NO}_{2}{ }^{-}-\mathrm{N}$ and $0.79 \mathrm{mg} / \mathrm{L}$ accumulation of $\mathrm{NH}_{4}{ }^{+}-\mathrm{N}$. The maximum removal rate of $\mathrm{NO}_{3}{ }^{-}-\mathrm{N}$ was $0.58 \mathrm{mg} / \mathrm{L} / \mathrm{h}$. In SNDM, the concentrations of $\mathrm{NH}_{4}{ }^{+}-\mathrm{N}, \mathrm{NO}_{2}{ }^{-}-\mathrm{N}$ and $\mathrm{NO}_{3}{ }^{-}-\mathrm{N}$ decreased from 10 to $0.59,0.78$ and $2.63 \mathrm{mg} / \mathrm{L}$. When $3 \mathrm{~N}$ sources coexisted, $\mathrm{NH}_{4}{ }^{+}-\mathrm{N}$ was used firstly because of its ability to bind to biomolecules directly. $63.93 \%$ of the initial $\mathrm{N}$ was removed from water and stored in thallus as intracellular $\mathrm{N}$. According to the $\mathrm{N}$ balance, $63-66 \%$ of the initial $\mathrm{N}$ was removed from water under different $\mathrm{N}$ sources by strain SD148BN12, and the removed N was stored into cells, without the release of nitrogenous 
gases. Hence, strain SD148BN12 was able to remove $\mathrm{N}$ rapidly from water through assimilating inorganic $\mathrm{N}$ into intracellular $\mathrm{N}$.

\subsection{Wastewater treatment and growth performance of M-B 3.3.1 $\mathrm{N}$ and $\mathrm{P}$ removal efficiency}

The $\mathrm{N}$ removal performance of the Chlorella sp.-Bacillus taeanensis SD148BN12 consortium was shown in Fig. $3 a$ and Fig. 3b. Within 8 days of culture in $M-B$, the concentration of TN decreased from 21.54 to $2.76 \mathrm{mg} / \mathrm{L}$, and the concentration of $\mathrm{NH}_{4}{ }^{+}-\mathrm{N}, \mathrm{NO}_{2}{ }^{-}-\mathrm{N}, \mathrm{NO}_{3}{ }^{-}-\mathrm{N}$ decreased to $0,0.08,0.74 \mathrm{mg} / \mathrm{L}$, respectively, which was significantly superior to $\mathrm{M}-\mathrm{O}$ and $\mathrm{B}-\mathrm{O}(\mathrm{p}<0.05)$. After 8 days, the $\mathrm{N}$ removal rates of $\mathrm{M}-\mathrm{B}$ tended to stagnate and 91.88\%, 99.97\%, 98.46\% and 91.74\% of $\mathrm{TN} \mathrm{NH}_{4}{ }^{+}-\mathrm{N}, \mathrm{NO}_{2}{ }^{-}-\mathrm{N}$ and $\mathrm{NO}_{3}{ }^{-}-\mathrm{N}$ were removed from the water at last, almost no $\mathrm{NH}_{4}{ }^{+}-\mathrm{N}$ and $\mathrm{NO}_{2}{ }^{-}-\mathrm{N}$ accumulated. In B-O, strain SD148BN12 grew faster during the first 4 days of culture, the $\mathrm{NH}_{4}{ }^{+}-\mathrm{N}$ content decreased from 10.23 to $1.31 \mathrm{mg} / \mathrm{L}$, but only $28.82 \%$ of TN was removed by strain

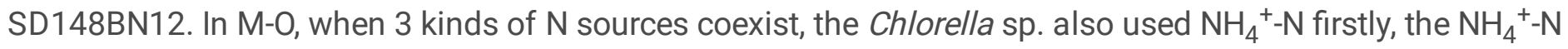
content reached the lowest at $0.084 \mathrm{mg} / \mathrm{L}$ on 6th day, but when the Chlorella sp. used $\mathrm{NO}_{2}{ }^{-}-\mathrm{N}$ and $\mathrm{NO}_{3}{ }^{-}-\mathrm{N}$ as N sources, a small amount of $\mathrm{NH}_{4}{ }^{+}-\mathrm{N}$ was accumulated. At last, 75.34\%, 99.76\%, 98.92\% and $55.45 \%$ of $\mathrm{TN}^{-\mathrm{NH}_{4}{ }^{+}-}$ $\mathrm{N}, \mathrm{NO}_{2}{ }^{-}-\mathrm{N}$ and $\mathrm{NO}_{3}{ }^{-}-\mathrm{N}$ were removed in $\mathrm{M}-\mathrm{O}$.

The removal performance of $P$ was shown in Fig. 3c. The removal efficiency of TP in M-B was always significantly higher than the other $(p<0.05)$. On 8th day, the TP concentration decreased from 2.04 to $0.19 \mathrm{mg} / \mathrm{L}$, $94.58 \%$ of TP was removed by M-B, which the TP removal efficiency in M-B was 2.07 and 4.51 times that of B-O and $\mathrm{M}-\mathrm{O}$.

\subsubsection{DO and $\mathrm{pH}$ levels}

The dissolved oxygen (DO) concentration in both M-B and B-O decreased rapidly on 2 day (Fig. 3d). With the photosynthesis of Chlorella sp., the concentration of DO in M-B gradually increased from $2.56 \mathrm{mg} / \mathrm{L}$ to 5.19 $\mathrm{mg} / \mathrm{L}$. In M-O, the DO concentration was always higher than the initial value, and the maximum DO concentration reached $8.30 \mathrm{mg} / \mathrm{L}$ on 8 days. The DO content of M-B was between that of M-O and B-O, changing the low DO level in B-O.

The $\mathrm{pH}$ values of the three conditions all increased during the culture process (Fig. $3 \mathrm{e}$ ). The $\mathrm{pH}$ value of $\mathrm{B}-\mathrm{O}$ had a small variation range and lower than 7.95. The $\mathrm{pH}$ value of $\mathrm{M}-\mathrm{O}$ continued to rise from 7.50 to 9.51 , while the $\mathrm{pH}$ value of M-B increased to 8.98 eventually. The presence of strain SD148BN12 changed the high $\mathrm{pH}$ in $\mathrm{M}-\mathrm{O}$.

\subsubsection{Cell growth and biomass accumulation}

The results measured chlorophyll-a concentration and Fv/Fm indicated that the co-culture of Chlorella sp. and strain SD148BN12 promoted the growth and photosynthetic activity of Chlorella sp. (Fig. 4a and Fig. 4b). After 8 days of culture, the chlorophyll-a concentration of M-B reached $4.24 \mathrm{mg} / \mathrm{L}$ and was 1.62 times that of M-O. The Fv/Fm in M-B increased to 0.74 and then decreased, which was always higher than that of M-O.

With the enhancement of photosynthetic activity for Chlorella sp. cells in M-B, the capacity of biomass production the consortium was increased significantly. On 8 days, the dry cell weight (DCW) of M-B reached 
$0.52 \mathrm{~g} / \mathrm{L}$, higher than the sum of M-O $(0.23 \mathrm{~g} / \mathrm{L})$ and B-O $(0.10 \mathrm{~g} / \mathrm{L})$, which remained stable over the next 6 days (Fig. 3a). The DCW continued to increase in M-O, while that gradually decreased after reaching the peak on 4 days in B-O. The number of viable bacteria in B-O increased rapidly, reaching a peak of $4.53 \times 10^{7} \mathrm{CFU} / \mathrm{mL}$ on the 4th day, and then decreased to $2.31 \times 10^{7} \mathrm{CFU} / \mathrm{mL}$ continuously (Fig. 4C). In contrast, the viable bacteria number had a more gradual upward or downward trend in $M-B$, and the maximum viable bacteria number $\left(4.16 \times 10^{7}\right.$ $\mathrm{CFU} / \mathrm{mL}$ ) appeared on the 6 th day and remained higher than that of $\mathrm{B}-\mathrm{O}$ thereafter.

The protein, carbohydrate and lipid contents of microorganism in the $\mathrm{N}$ removal process were shown in Fig. 5. After culture, the protein content in M-B increased to $23.32 \%$ of DCW, which was slightly higher than that M-O $(p>0.05)$. The carbohydrate and lipid contents increased to $19.31 \%$ and $36.06 \%$ of DCW in M-B, improving by $27.72 \%$ and $39.88 \%$ respectively compared with those in $\mathrm{M}-0$.

\section{4 $\mathrm{N}$ removal performance of $\mathrm{M}-\mathrm{B}$ under different environmental factors}

M-B could remove more than $70 \%$ of $\mathrm{TN}, 99 \%$ of $\mathrm{NH}_{4}{ }^{+}-\mathrm{N}$ and $98 \%$ of $\mathrm{NO}_{2}{ }^{-} \mathrm{N}$ at the temperature of $20-30{ }^{\circ} \mathrm{C}$, salinity of 20-40\%o, light intensity of 50-200 $\mu$ mol photons $\mathrm{m}^{-2} \mathrm{~s}^{-1}, \mathrm{pH}$ of 6-9, C/N ratio of 1-10, N/P ratio of 4$20, \mathrm{~N}$ concentration of $1-50 \mathrm{mg} / \mathrm{L}$. TN removal efficiency in M-B was higher than $\mathrm{M}-\mathrm{O}$ and B-O under following environmental factors (Table S1).

Temperature. As shown in Fig. 6a, at 20-30 ${ }^{\circ} \mathrm{C}, \mathrm{NH}_{4}{ }^{+}-\mathrm{N}-\mathrm{RE}\left(\mathrm{NH}_{4}{ }^{+} \mathrm{N}-\mathrm{RE}\right)$ and $\mathrm{NO}_{2}{ }^{-}-\mathrm{N}$ removal efficiency $\left(\mathrm{NO}_{2}{ }^{-}-\mathrm{N}-\right.$ RE) of M-B exceeded $99 \%$ and TN removal efficiency (TNRE) and DCW went up as the temperature, with no significant difference $(p>0.05)$. At 15 and $40{ }^{\circ} \mathrm{C}, \mathrm{N}$ removal and biomass production performance of M-B were retarded $(p<0.05)$.

Salinity. As shown in Fig. 6b, at high salinity (20-40\%o), $\mathrm{NH}_{4}{ }^{+}-\mathrm{N}-\mathrm{RE}$ and $\mathrm{NO}_{2}{ }^{-}-\mathrm{N}-\mathrm{RE}$ surpassed $99 \%$. At 30\%, TNRE and DCW were higher than other salinities. The lower salinity (0-10\%o) was not conducive to $\mathrm{N}$ removal, and $\mathrm{N}$ removal and biomass production performance fortified as the salinity within the range. As the salinity was 0 , M-B was significantly inhibited and the TNRE was reduced to $13.39 \%(p<0.05)$.

pH. As shown in Fig. $6 \mathrm{c}$, at $\mathrm{pH}$ of 7-9, TNRE, $\mathrm{NH}_{4}{ }^{+}-\mathrm{N}-\mathrm{RE}$ and $\mathrm{NO}_{2}{ }^{-}-\mathrm{N}-\mathrm{RE}$ of $\mathrm{M}-\mathrm{B}$ exceeded $85 \%, 99 \%$ and $98 \%$, respectively, with no significant difference $(p>0.05)$. At $\mathrm{pH}$ of 6 , the TNRE decreased significantly but still reached $80.73 \%(p<0.05)$.

Light intensity. As shown in Fig. $6 \mathrm{~d}$, when the light intensity was 50-200 $\mu \mathrm{mol}$ photons $\mathrm{m}^{-2} \mathrm{~s}^{-1}$, there were no significant differences among the treatment groups ( $p>0.05)$. TNRE, $\mathrm{NH}_{4}{ }^{+}-\mathrm{N}-\mathrm{RE}, \mathrm{NO}_{2}{ }^{-}{ }^{-} \mathrm{N}-\mathrm{RE}$ and DCW maintained at high levels, over $88 \%, 99.5 \%, 99.5 \%$ and $0.52 \mathrm{~g} / \mathrm{L}$ respectively. Below $50 \mu \mathrm{mol}$ photons $\mathrm{m}^{-2} \mathrm{~s}^{-1}$, higher light intensity improved the DCW and N removal efficiency of M-B $(p<0.05)$.

$\mathrm{C} / \mathrm{N}$ ratio. As shown in Fig. $6 \mathrm{e}$, when $\mathrm{C} / \mathrm{N}$ ratio was $2.5-10 \mathrm{mg} / \mathrm{L}$, there were no significant differences in biomass production and $\mathrm{N}$ removal among different treatment groups $(p>0.05)$, with the highest $\mathrm{N}$ removal efficiency and DCW at 5. Higher (15) and lower $(0,1) \mathrm{C} / \mathrm{N}$ ratios inhibited DCW and TNRE $(p<0.05)$. 
N/P ratio. As shown in Fig. 6f, When N/P ratio was at 4-20, high $\mathrm{N}$ removal efficiency and DCW could be achieved by M-B. TNRE and DCW reached the highest at the N/P ratio of 7 . When N/P ratio was at 40 , the $N$ removal capacity was significantly reduced $(p<0.05)$.

$N$ concentration. As shown in Fig. $6 \mathrm{~g}$, when the $\mathrm{N}$ concentration was $1-10 \mathrm{mg} / \mathrm{L}$, the TNRE was more than $92 \%$, $99 \%, 99 \%$, respectively. When the $\mathrm{N}$ concentration increased to $20 \mathrm{mg} / \mathrm{L}$, the TNRE decreased to $86.43 \%$. When the $\mathrm{N}$ concentration increased to $50 \mathrm{mg} / \mathrm{L}$, the TNRE decreased to $75.33 \%$, and the $\mathrm{NH}_{4}{ }^{+}-\mathrm{N}-\mathrm{RE}$ and $\mathrm{NO}_{2}{ }^{-} \mathrm{N}-\mathrm{RE}$ were still close to $100 \%$. At the $\mathrm{N}$ concentration of $1-50 \mathrm{mg} / \mathrm{L}$, DCW of M-B increased significantly with the rise of $\mathrm{N}$ concentration $(p<0.05)$.

\section{5 $\mathrm{N}$ and $\mathrm{P}$ removal of $\mathrm{M}-\mathrm{B}$ in real mariculture water and wastewater}

The MW-1 treatment performance by M-B was shown in the Fig. 7a, 7b, 7c and 7d. After 14-day continuous treatment, $\mathrm{NH}_{4}{ }^{+}-\mathrm{N}$ concentration were decreased from 2.01 to $0.02,0,0 \mathrm{mg} / \mathrm{L}$, and $\mathrm{NO}_{2}{ }^{-}-\mathrm{N}$ were reduced from 1.11 to $0.75,0.01,0 \mathrm{mg} / \mathrm{L}$ when the inoculum cell density of the Chlorella sp. (cell/mL) / strain SD148BN12 (CFU/mL) were $10^{4}: 10^{4}, 10^{5}: 10^{5}, 10^{6}: 10^{6}$ (group $10^{4}, 10^{5}, 10^{6}$ ), respectively. Meanwhile, in the group of $10^{4}, 10^{5}$, $10^{6}$, there were $67.11 \%, 87.06 \%, 89.83 \%$ of TN and $59.38 \%, 70.98 \%, 79.03 \%$ of TP removed from water. The increase of initial inoculation density was beneficial to improve the $\mathrm{N}$ and $\mathrm{P}$ removal efficiency. The $\mathrm{MW}-2$ treatment performance by M-B was shown in the Fig. 7e and 7f. After treatment, TN in group $10^{4}, 10^{5}, 10^{6}$ were decreased from 13.1 to $1.50,1.37,1.22 \mathrm{mg} / \mathrm{L}$, while TP were reduced from 2.04 to $0.16,0.10,0.11 \mathrm{mg} / \mathrm{L}$. The higher the initial cell density, the higher the removal rates of $\mathrm{N}$ and $\mathrm{P}$, but different treatment groups could achieve similar removal efficiency after 14-day treatment.

\section{Discussion}

In order to optimize the removal efficiency of $\mathrm{N}$ and $\mathrm{P}$ in wastewater treatment and control the $\mathrm{N}, \mathrm{P}$ pollution caused by intensive aquaculture, 36 strains isolated from aquaculture environments were used to co-culture with Chlorella sp.. A strain, Bacillus taeanensis SD148BN12 with synergistic effect with Chlorella sp. on N removal was screened and the Chlorella sp.-Bacillus taeanensis SD148BN12 symbiotic consortium was constructed. M-B had excellent N, $\mathrm{P}$ removal performance and biomass accumulation under aerobic conditions. The study provided a promising microalgae-bacteria consortium for synchronous removal of $\mathrm{N}$ and $\mathrm{P}$ from wastewater, which could solve the $\mathrm{N}$ pollution effectively and make up for the vacancy of efficient biological $\mathrm{P}$ removal process in the aquaculture wastewater.

\subsection{Biosafety of strain SD148BN12}

Biosafety was important for the application of bacteria used in aquatic environment. In this study, strain SD148BN12 had no hemolytic activity on the blood agar plate, which indicated it had no hidden danger of producing hemolysin to cause membrane damage and cell cytolysis (Zhang et al. 2021a). In the test of antibiotic sensitivity, strain SD148BN12 had high sensitivity to most antibiotics, but was highly resistant to some quinolone, sulfonamide, tetracycline, aminoglycoside, macrolide antibiotics and bacitracin. It had been reported that above antibiotics were often detected in aquaculture systems (Gao et al. 2012, Liu et al. 2017b), and the long-term pressure from the antibiotics might cause strain SD148BN12 to carry the resistance genes 
(Shahi et al. 2018). At present, most of the bacteria used in wastewater treatment had the indeterminate safety (Zhang et al. 2020b), and the evaluation of the hemolytic activity and antibiotic sensitivity of strain SD148BN12 preliminarily ensured non-pathogenicity and application feasibility of strain SD148BN12 in water environment.

\section{$4.2 \mathrm{~N}$ and $\mathrm{P}$ removal performance of $\mathrm{M}-\mathrm{B}$}

In SWM with the C/N ratio of 5, M-B removed $87.19 \%$ of TN and $90.95 \%$ of TP within 8 days. Compared with the results of a Microcystis aeruginosa-Bacillus licheniformis consortium cultured in synthetic wastewater (Ji et al. 2018), M-B achieved similar $N$ removal amount and higher $P$ removal amount. In $B-0$, the maximum removal efficiency of strain SD148BN12 for TN and inorganic N were only $28.82 \%$ and $59.75 \%$. However, in HNM, DM and SNDM with the $\mathrm{C} / \mathrm{N}$ ratio of 10 , the removal efficiency of TN and inorganic $\mathrm{N}$ were higher than $63 \%$ and $88 \%$ within $48 \mathrm{~h}$ respectively, which was comparable to the current reported denitrifier isolated from aquaculture systems (Yun et al. 2019, Zhao et al. 2019). Correspondingly, the $\mathrm{N}$ removed from water was assimilated into intracellular $\mathrm{N}$, avoiding $\mathrm{N}$ loss and noxious gases of $\mathrm{N}_{\mathrm{x}} \mathrm{O}$. According to the reports, the $\mathrm{C} / \mathrm{N}$ ratio determining the energy supply played an important role for the $\mathrm{N}$ removal capability of bacteria (Hou et al. 2021, Su et al. 2021). The low $\mathrm{C} / \mathrm{N}$ ratio in SWM might be the main reason to limit the $\mathrm{N}$ removal efficiency of strain SD148BN12 (Table S1), implying the removal of TN mainly depended on the Chlorella sp. in M-B. On the 8th day, the TN removal efficiency in M-B was higher than the summation of that in B-O (25.50\%) and M-O (48.69\%), suggesting that the interactions between strain SD148BN12 and the Chlorella sp. had positive effect on N removal efficiency of M-B. Likewise, the TP removal efficiency in M-B was higher than the summation of that in B-O (20.16\%) and M-O (43.83\%) on the 8th day. Due to the slightly P removal efficiency of strain SD148BN12, the $\mathrm{P}$ removal in M-B mainly relied on the uptake capacity of the Chlorella sp.. The similar researches agreed that bacteria growing much faster than microalgae played a major role in $\mathrm{N}$ and $\mathrm{P}$ removal in the early stage of experiment, but the contribution of bacteria to N, P removal was limited due to the finite nutrient (especially organic carbon) (Li et al. 2018, Liu et al. 2017a). The higher removal efficiency of $\mathrm{N}$ and $\mathrm{P}$ in M-B was primarily attributed to the conspicuous capability of N, P absorption for the Chlorella sp. enhancing by strain SD148BN12 (Liu et al. 2017a). In a study about co-culture of Chlorella vulgaris and Bacillus licheniformis, the presence of Bacillus increased the $\mathrm{N}$ removal efficiency of Chlorella from 29-78\% (Liang et al. 2013), and another study combining Effective Microorganism (EM-1) and Chlorella sp. to treat aquaculture wastewater showed that the addition of EM-1 increased the TP removal efficiency of microalgae Chlorella sp. from 49.73-99.15\% (Lananan et al. 2014), which proved the superiority for improving the N, P removal efficiency by co-culture of microalgae and bacteria. The co-culture mode of M-B provided a new approach to solute the common problems of the N, P control in wastewater treatment, such as: the removal capacity of bacteria was limited by the low C/N ratio, bacteria with efficient $P$ removal performance were difficult to isolated (Zhang et al. 2020b), single microalgae systems needed relatively long treatment cycles and released excessive alkali resulting in high $\mathrm{pH}$ in effluent (Li et al. 2018, Peng et al. 2021). This study expanded the application prospect of the Chlorella sp. and strain SD148BN12, as well, it enriched the rare information on the efficient removal of $\mathrm{N}$ and $\mathrm{P}$ from saline wastewater.

\subsection{Biomass production performance of $\mathrm{M}-\mathrm{B}$}

Biomass analysis showed the Chlorella sp. were the main providers of DCW in M-B. After 8 days of culture, the DCW of M-B was higher than the sum of that of $\mathrm{M}-\mathrm{O}$ and $\mathrm{B}-\mathrm{O}$, suggesting that co-culture with bacteria might improve the biomass yield of the Chlorella sp. (Liu et al. 2017a). In M-O, the contents of protein, carbohydrate and lipid in biomass were consistent with those of ranges of reported Chlorella species (Cao et al. 2020,

Page $12 / 24$ 
Guccione et al.,2014). Compared with M-O, M-B maintained reliable contents of protein and carbohydrate, furthermore, M-B increased the content of lipid greatly. This lipid content ( $36.06 \%$ of DCW) was on the high level for the reported lipid proportions of Chlorella species and microalgae-bacteria consortia (Guccione et al.,2014, Li et al. 2018, Rasouli et al. 2018). Therefore, M-B would provide valuable biomass by recycling N, P from wastewater and optimizing the biomass composition. Currently, emerging biotechnology called for coupling to wastewater treatment and biomass production and using resources in wastewater to produce high-value chemicals, animal feed and biofuels through microalgae-bacteria consortia (Ramanan et al. 2016, Saravanan et al. 2021). This research provided promising biomaterials for the sustainable production and development.

\subsection{Characterization of interaction between microalgae and bacteria in M-B}

The synergistic interactions between Chlorella sp. and strain SD148BN12 provided support for the efficient operation of M-B. Higher Fv/Fm showed higher photosynthetic activity and lower environmental stress of the Chlorella sp. under M-B (He et al. 2015). On the 8th day, the chlorophyll-a concentration and the cell density of Chlorella sp. in M-B were higher than that in M-O. These phenomena indicated that strain SD148BN12 had a positive effect on the photosynthetic activity of Chlorella sp., which enhanced the growth of Chlorella sp. and the removal of $\mathrm{N}$, P. The dependence of $\mathrm{CO}_{2} / \mathrm{O}_{2}$ between microalgae and aerobic bacteria was considered to be the basic interaction for microalgae-bacteria consortia in wastewater treatment (Wang et al. 2020). In this study, differences of DO in M-O, B-O and M-B possibly implied that $\mathrm{O}_{2}$ released by Chlorella sp. was provided for strain SD148BN12 (Lananan et al. 2014). In return, strain SD148BN12 would stimulate the Chlorella sp. activity by release $\mathrm{CO}_{2}$ produced by respiration (Ferro et al. 2019). Furthermore, at later stage of the experiment, the live bacteria continued to decline in both $\mathrm{M}-\mathrm{B}$ and $\mathrm{B}-\mathrm{O}$ due to depletion of nutrients (especially the organic carbon) in SWM, but the number of viable bacteria in M-B was still higher than that in the B-O. It might be put down to the release of nutrients (such as dissolved organic carbon) by microalgae metabolism that allow more bacteria to survive. (Natrah et al. 2014, Peng et al. 2021). To sum up, the Chlorella sp. and strain SD148BN12 mainly showed cooperative interactions in cell growth, photosynthetic activity and material exchange, which was beneficial for M-B to remain efficient and stable in wastewater treatment.

\subsection{Evaluation of environmental adaptability of M-B}

The single-factor experiment demonstrated the superior adaptability of M-B to the changes of physical and chemical factors of water. When environmental parameters changed, different from the large fluctuation of removal performance in $\mathrm{B}-\mathrm{O}$ and $\mathrm{M}-\mathrm{O}, \mathrm{M}-\mathrm{B}$ could maintain a stable high $\mathrm{N}$ removal efficiency in a wider range of environmental parameters (Table S1). It was worth mentioning that M-B relieved the inhibition for single microalgae and single bacteria cultivation of $\mathrm{N}$ removal efficiency caused by the change of carbon, $\mathrm{N}$ and $\mathrm{P}$ contents and $\mathrm{pH}$ value in water. However, the ability of $\mathrm{M}-\mathrm{B}$ to deal with the impacts of high temperature $\left(40^{\circ} \mathrm{C}\right)$, low temperature $\left(15^{\circ} \mathrm{C}\right)$ and low salinity $(0-5 \%)$ on $\mathrm{N}$ removal was still weak. It had been proved that temperature and salinity were the key factors affecting biological removal efficiency. In many similar studies, higher or lower temperature could decrease microbial enzyme activity and the lack of essential ions might inhibit microbial growth gravely (Su et al. 2021, Zhang et al. 2021b). According to studies, in most of mariculture environments, temperatures were higher than $20^{\circ} \mathrm{C}$ (Chang et al. 2020, Kumlu et al. 2010), C/N ratios were lower than 5 (Huang et al. 2020b), N/P ratios were generally lower than 20 (Chang et al. 2020, Han et al. 2020, Hoang et al. 2020, Xu et al. 2019, Yang et al. 2017), pH values were at 7-9 (Su et al. 2021), as well as 
the $\mathrm{N}$ concentrations were generally lower than $20 \mathrm{mg} / \mathrm{L}$ in pond water and effluent (Huang et al. 2021a). According to the results of this study, M-B could remove $\mathrm{N}$ considerably from medium and high salinity aquaculture water and wastewater, and almost completely eliminate $\mathrm{NH}_{4}{ }^{+}-\mathrm{N}$ and $\mathrm{NO}_{2}{ }^{-}-\mathrm{N}$ which were toxic to aquatic animals. It was reported that the $\mathrm{N}$ concentrations were close to $50 \mathrm{mg} / \mathrm{L}$ in high strength mariculture wastewater (Zhang et al. 2021b) and saline domestic sewage (Salmanikhas et al. 2016, Wu et al. 2017), according with the range of efficient $\mathrm{N}$ removal for $\mathrm{M}-\mathrm{B}$, which suggested that $\mathrm{M}-\mathrm{B}$ also had potential application value in more types of wastewater treatment.

\subsection{Application of M-B in real wastewater treatment}

Different from synthetic media, the real wastewater had more complex chemical and biological composition, which might practically affect the survival and $\mathrm{N}$ and $\mathrm{P}$ removal performance of $\mathrm{M}-\mathrm{B}$ (Zhang et al. 2021a). There was little reduction of $\mathrm{N}$ and $\mathrm{P}$ in the mariculture water and wastewater non-inoculated $\mathrm{M}-\mathrm{B}$, while there was a significant removal performance in mariculture water and wastewater inoculated the consortium, suggesting the inoculated $M-B$, rather than indigenous microorganism, played the major role in actual treatment. Studies proved that increasing the inoculum density in a certain range could improve the removal capacity of microorganisms (Li et al. 2018, Zhang et al. 2020b). In the study, the higher inoculation density of M-B was beneficial to establish a stable combination rapidly under different environmental conditions and improve the removal rate and efficiency of $\mathrm{N}$ and $\mathrm{P}$. By comparison with some studies on aquaculture wastewater treatment by microalgae-bacteria consortiums, the consorts achieved the similar removal efficiency of $\mathrm{N}$ and $\mathrm{P}$ with lower light energy (Han et al. 2020). The results showed that M-B could remove $\mathrm{N}$ and $\mathrm{P}$ efficiently in the medium of real wastewater, which provided strong support for practical engineering applications.

\section{Conclusion}

A novel microalgae-bacteria symbiotic consortium of with higher N, P removal efficiency and biomass production was constructed by combining Chlorella sp. strain MACC/C95 and Bacillus taeanensis SD148BN12. The aerobic $\mathrm{N}$ removal capability by assimilation and biosafety of the strain SD148BN12 were identified to ensure its safe and eco-friendly application in aquatic environments. M-B had wide adaptation to environmental change and showed substantial removal performance of $\mathrm{N}$ and $\mathrm{P}$ in marine wastewater. The main interactions between the Chlorella sp. and strain SD148BN12 for N, P removal and cell growth were synergetic during cultivation. The study provided a reliable microalgae-bacteria consortium for the stable, efficient and resourceful treatment of wastewater, and enriched the research about removal process of N, P in aquaculture wastewater.

\section{Declarations}

\section{Funding information}

This work was supported by the Key Field Research and Development Program of Guangdong Province [grant number 2020B0202010009].

\section{Author contributions}

Liping Liu: Conceptualization, Methodology, Investigation, Formal analysis, Writing - original draft. Mengyu Zhang: Investigation, Formal analysis. Yun Li: Supervision, Conceptualization, Writing - review \& editing. Luqing 
Pan: Investigation, Formal analysis. Le Dou: Investigation. Zhaopeng Su: Investigation.

\section{Conflict of interest}

The authors declare that they have no conflict of interest.

\section{Ethics approval and consent to participate}

Not applicable.

\section{Consent for publication}

Not applicable.

\section{Availability of data and materials}

All data generated or analyzed during this study are included in this published article.

\section{References}

1. Bligh ELG, Dyer WJA (1959) A rapid method of total lipid extraction and purification. Can J Biochem Physiol 37:911-917

2. Cao M, Kang J, Gao Y, Wang X, Pan X, Liu P (2020) Optimization of cultivation conditions for enhancing biomass, polysaccharide and protein yields of Chlorella sorokiniana by response surface methodology. Aquac Res 51:2456-2471

3. Chang ZQ, Neori A, He YY, Li JT, Qiao L, Preston SI, Liu P, Li J (2020) Development and current state of seawater shrimp farming, with an emphasis on integrated multi-trophic pond aquaculture farms, in China a review. Reviews in Aquaculture 12:2544-2558

4. Feng S, Liu F, Zhu S, Feng P, Wang Z, Yuan Z, Shang C, Chen H (2020) Performance of a microalgalbacterial consortium system for the treatment of dairy-derived liquid digestate and biomass production. Bioresour Technol 306:123101

5. Ferro L, Colombo M, Posadas E, Funk C, Muñoz R (2019) Elucidating the symbiotic interactions between a locally isolated microalga Chlorella vulgaris and its co-occurring bacterium Rhizobium sp. in synthetic municipal wastewater. J Appl Phycol 31:2299-2310

6. Gao P, Mao D, Luo Y, Wang L, Xu B, Xu L (2012) Occurrence of sulfonamide and tetracycline-resistant bacteria and resistance genes in aquaculture environment. Water Res 46:2355-2364

7. Guccione A, Biondi N, Sampietro G, Rodolfi L, Bassi N, Tredici MR (2014) Chlorella for protein and biofuels: from strain selection to outdoor cultivation in a green wall panel photobioreactor. Biotechnol Biofuels 7:84

8. Han W, Mao Y, Wei Y, Shang P, Zhou X (2020) Bioremediation of Aquaculture Wastewater with AlgalBacterial Biofilm Combined with the Production of Selenium Rich Biofertilizer. Water 12.

9. He Q, Yang H, Wu L, Hu C (2015) Effect of light intensity on physiological changes, carbon allocation and neutral lipid accumulation in oleaginous microalgae. Bioresour Technol 191:219-228

10. Hoang MN, Nguyen PN, Bossier P (2020) Water quality, animal performance, nutrient budgets and microbial community in the biofloc-based polyculture system of white shrimp, Litopenaeus vannamei and gray 
mullet, Mugil cephalus. Aquaculture 515

11. Hou P, Sun X, Fang Z, Feng Y, Guo Y, Wang Q, Chen C (2021) Simultaneous removal of phosphorous and nitrogen by ammonium assimilation and aerobic denitrification of novel phosphate-accumulating organism Pseudomonas chloritidismutans K14. Bioresour Technol 340:125621

12. Huang F, Pan L, Lv N, Tang X (2017) Characterization of novel Bacillus strain N31 from mariculture water capable of halophilic heterotrophic nitrification-aerobic denitrification. J Biosci Bioeng 124:564-571

13. Huang F, Pan L, He Z, Zhang M, Zhang M (2020a) Identification, interactions, nitrogen removal pathways and performances of culturable heterotrophic nitrification-aerobic denitrification bacteria from mariculture water by using cell culture and metagenomics. Sci Total Environ 732:139268

14. Huang F, Pan L, He Z, Zhang M, Zhang M (2020b) Culturable heterotrophic nitrification-aerobic denitrification bacterial consortia with cooperative interactions for removing ammonia and nitrite nitrogen in mariculture effluents. Aquaculture 523.

15. Huang F, Pan L, He Z, Zhang M, Zhang M (2021a) Heterotrophic nitrification-aerobic denitrification characteristics and antibiotic resistance of two bacterial consortia from Marinomonas and Halomonas with effective nitrogen removal in mariculture wastewater. J Environ Manage 279:111786

16. Huang X, Jiang D, Ni J, Xie D, Li Z (2021b) Removal of ammonium and nitrate by the hypothermia bacterium Pseudomonas putida Y-9 mainly through assimilation. Environmental Technology \& Innovation, p 22

17. Ji X, Jiang M, Zhang J, Jiang X, Zheng Z (2018) The interactions of algae-bacteria symbiotic system and its effects on nutrients removal from synthetic wastewater. Bioresour Technol 247:44-50

18. Kumlu M, Kumlu M, Turkmen S (2010) Combined effects of temperature and salinity on critical thermal minima of pacific white shrimp Litopenaeus vannamei (Crustacea: Penaeidae). J Therm Biol 35:302-304

19. Lananan F, Abdul Hamid SH, Din WNS, Ali Na, Khatoon H, Jusoh A, Endut A (2014) Symbiotic bioremediation of aquaculture wastewater in reducing ammonia and phosphorus utilizing Effective Microorganism (EM-1) and microalgae (Chlorella sp.). Int Biodeterior Biodegrad 95:127-134

20. Li Y, Wang Y, Fu L, Gao Y, Zhao H, Zhou W (2017) Aerobic-heterotrophic nitrogen removal through nitrate reduction and ammonium assimilation by marine bacterium Vibrio sp. Y1-5. Bioresour Technol 230:103111

21. Li Y, Wang Y, Gao Y, Zhao H, Zhou W (2018) Seawater toilet flushing sewage treatment and nutrients recovery by marine bacterial-algal mutualistic system. Chemosphere 195:70-79

22. Liang Z, Liu Y, Ge F, Xu Y, Tao N, Peng F, Wong M (2013) Efficiency assessment and pH effect in removing nitrogen and phosphorus by algae-bacteria combined system of Chlorella vulgaris and Bacillus licheniformis. Chemosphere 92:1383-1389

23. Liu H, Lu Q, Wang Q, Liu W, Wei Q, Ren H, Ming C, Min M, Chen P, Ruan R (2017a) Isolation of a bacterial strain, Acinetobacter sp. from centrate wastewater and study of its cooperation with algae in nutrients removal. Bioresour Technol 235:59-69

24. Liu X, Steele JC, Meng XZ (2017b) Usage, residue, and human health risk of antibiotics in Chinese aquaculture: A review. Environ Pollut 223:161-169

25. Lowry O, Rosebrough N, Farr A, Randall R (1951) Protein measurement with the Folin phenol reagent. J Biol Chem 193:265-275 
26. Malibari R, Sayegh F, Elazzazy AM, Baeshen MN, Dourou M, Aggelis G (2018) Reuse of shrimp farm wastewater as growth medium for marine microalgae isolated from Red Sea - Jeddah. J Clean Prod 198:160-169

27. Mohsenpour SF, Hennige S, Willoughby N, Adeloye A, Gutierrez T (2021) Integrating micro-algae into wastewater treatment: A review. Sci Total Environ 752:142168

28. Monsigny M, Petit C, Roche AC (1988) Colorimetric determination of neutral sugars by a resorcinol sulfuric acid micromethod. Anal Biochem 175:525-530

29. Natrah FMI, Bossier P, Sorgeloos P, Yusoff FM, Defoirdt T (2014) Significance of microalgal-bacterial interactions for aquaculture. Reviews in Aquaculture 6:48-61

30. Peng H, de- Bashan LE, Higgins BT (2021) Comparison of algae growth and symbiotic mechanisms in the presence of plant growth promoting bacteria and non-plant growth promoting bacteria.Algal Research53

31. Ramanan R, Kim BH, Cho DH, Oh HM, Kim HS (2016) Algae-bacteria interactions: Evolution, ecology and emerging applications. Biotechnol Adv 34:14-29

32. Rasouli Z, Valverde-Pérez B, D’Este M, De Francisci D, Angelidaki I (2018) Nutrient recovery from industrial wastewater as single cell protein by a co-culture of green microalgae and methanotrophs. Biochem Eng $\mathrm{J}$ 134:129-135

33. Salmanikhas N, Tizghadam M, Rashidi Mehrabadi A (2016) Treatment of saline municipal wastewater using hybrid growth system. J Biol Eng 10:9

34. Saravanan A, Kumar PS, Varjani S, Jeevanantham S, Yaashikaa PR, Thamarai P, Abirami B, George CS (2021) A review on algal-bacterial symbiotic system for effective treatment of wastewater. Chemosphere 271:129540

35. Shahi N, Sharma P, Pandey J, Bisht I, Mallik SK (2018) Characterization and pathogenicity study of Chryseobacterium scophthalmum recovered from gill lesions of diseased golden mahseer, Tor putitora (Hamilton, 1822) in India. Aquaculture 485:81-92

36. Su Y (2021) Revisiting carbon, nitrogen, and phosphorus metabolisms in microalgae for wastewater treatment. Sci Total Environ 762:144590

37. Su Z, Li Y, Pan L, He Z, Le D, Liu L, Zhang M (2021) Nitrogen removal performance, quantitative detection and potential application of a novel aerobic denitrifying strain, Pseudomonas sp. GZWN4 isolated from aquaculture water. Bioprocess Biosyst Eng 44:1237-1251

38. Wang X, Miao J, Pan L, Li Y, Lin Y, Wu J (2019) Toxicity effects of p-choroaniline on the growth, photosynthesis, respiration capacity and antioxidant enzyme activities of a diatom, Phaeodactylum tricornutu. Ecotoxicol Environ Saf 169:654-661

39. Wang Y, Wang S, Sun L, Sun Z, Li D (2020) Screening of a Chlorella-bacteria consortium and research on piggery wastewater purification.Algal Research47

40. Wu KC, Yau YH, Ho KC (2017) Capability of microalgae for local saline sewage treatment towards biodiesel production. IOP Conference Series: Earth and Environmental Science 82

41. Xu W, Xu Y, Huang X, Hu X, Xu Y, Su H, Li Z, Yang K, Wen G, Cao Y (2019) Addition of algicidal bacterium CZBC1 and molasses to inhibit cyanobacteria and improve microbial communities, water quality and shrimp performance in culture systems. Aquaculture 502:303-311 
42. Yang P, Lai DYF, Jin B, Bastviken D, Tan L, Tong C (2017) Dynamics of dissolved nutrients in the aquaculture shrimp ponds of the Min River estuary, China: Concentrations, fluxes and environmental loads. Sci Total Environ 603-604:256-267

43. Yun L, Yu Z, Li Y, Luo P, Jiang X, Tian Y, Ding X (2019) Ammonia nitrogen and nitrite removal by a heterotrophic Sphingomonas sp. strain LPN080 and its potential application in aquaculture. Aquaculture 500:477-484

44. Zhang LJ, Xie Y, Ding LY, Qiao XJ, Tao HC (2020a) Highly efficient ammonium removal through nitrogen assimilation by a hydrogen-oxidizing bacterium, Ideonella sp. TH17. Environ Res 191:110059

45. Zhang M, Pan L, Liu L, Su C, Dou L, Su Z, He Z (2020b) Phosphorus and nitrogen removal by a novel phosphate-accumulating organism, Arthrobacter sp. HHEP5 capable of heterotrophic nitrification-aerobic denitrification: Safety assessment, removal characterization, mechanism exploration and wastewater treatment. Bioresour Technol 312:123633

46. Zhang M, Pan L, Su C, Liu L, Dou L (2021a) Simultaneous aerobic removal of phosphorus and nitrogen by a novel salt-tolerant phosphate-accumulating organism and the application potential in treatment of domestic sewage and aquaculture sewage. Sci Total Environ 758:143580

47. Zhang Z, Guo L, Liao Q, Gao M, Zhao Y, Jin C, She Z, Wang G (2021b) Bacterial-algal coupling system for high strength mariculture wastewater treatment: Effect of temperature on nutrient recovery and microalgae cultivation. Bioresour Technol 338:125574

48. Zhao K, Tian X, Li H, Dong S, Jiang W (2019) Characterization of a novel marine origin aerobic nitrifyingdenitrifying bacterium isolated from shrimp culture ponds. Aquac Res 50:1770-1781

\section{Tables}

Table 1 Antibiotic susceptibility of Bacillus taeanensis SD148BN12 to different antibiotics. 


\begin{tabular}{|c|c|c|c|}
\hline \multicolumn{2}{|l|}{ Antibiotic class } & $\begin{array}{l}\text { Antibiotic content } \\
\text { per disk }\end{array}$ & $\begin{array}{l}\text { Inhibition zone } \\
\text { diameter (mm) }\end{array}$ \\
\hline \multirow[t]{3}{*}{ Aminoglycosides } & Streptomycin & $10 \mu \mathrm{g}$ & + \\
\hline & Neomycin & $30 \mu \mathrm{g}$ & +++ \\
\hline & Gentamicin & $10 \mu \mathrm{g}$ & + \\
\hline \multirow[t]{2}{*}{ Amphenicols } & Chloramphenicol & $30 \mu \mathrm{g}$ & +++ \\
\hline & Florfenicol & $30 \mu \mathrm{g}$ & ++++ \\
\hline \multirow[t]{2}{*}{ Cephalosporins } & Cefotaxime & $30 \mu \mathrm{g}$ & ++++ \\
\hline & Cefoperazone & $75 \mu \mathrm{g}$ & +++++ \\
\hline Furanes & Furazolidone & $100 \mu \mathrm{g}$ & +++++ \\
\hline \multirow[t]{2}{*}{ Macrolides } & Erythromycin & $15 \mu g$ & + \\
\hline & Roxithromycin & $15 \mu \mathrm{g}$ & +++ \\
\hline \multirow[t]{3}{*}{ Penicillins } & Penicillin & $10 \mathrm{U}$ & +++ \\
\hline & Ampicillin & $10 \mu \mathrm{g}$ & + \\
\hline & Augmentin & $20 / 10 \mu \mathrm{g}$ & ++++ \\
\hline Polypeptides & Bacitracin & $0.04 U$ & + \\
\hline \multirow[t]{3}{*}{ Quinolones } & Ofloxacin & $5 \mu g$ & + \\
\hline & Norfloxacin & $10 \mu \mathrm{g}$ & + \\
\hline & Ciprofloxacin & $5 \mu g$ & + \\
\hline Sulfonamides & Sulfisoxazole & $300 \mu \mathrm{g}$ & - \\
\hline \multirow[t]{2}{*}{ Tetracyclines } & Tetracycline & $30 \mu \mathrm{g}$ & + \\
\hline & Doxycycline & $30 \mu \mathrm{g}$ & +++ \\
\hline Others & Fosfomycin & $200 \mu \mathrm{g}$ & ++ \\
\hline
\end{tabular}

$-:$ Inhibition zone diameter of $0 \mathrm{~mm}$;

+: Inhibition zone diameter between 10-15 mm, ++: Inhibition zone diameter between 16-20 mm;

+++: Inhibition zone diameter between 21-25 mm, ++++: Inhibition zone diameter between 26-30 mm;

+++++: Inhibition zone diameter between 31-35 mm.

Table 2 Nitrogen balance of Bacillus taeanensis SD148BN12 under different nitrogen sources. 
Media Initial nitrogen concentration 『mg/L)

\begin{tabular}{|c|c|c|c|c|c|c|c|}
\hline & & $\mathrm{NH} \otimes \mathbb{Z}-\mathrm{N}$ & NO怄-N & NO怄-N & Organic N & $\begin{array}{l}\text { Intracellular } \\
\mathrm{N}\end{array}$ & \\
\hline HNM & $10.13 \pm 0.05$ & $0.85 \pm 0.01$ & $0.03 \pm 0.006$ & $0.30 \pm 0.001$ & $2.24 \pm 0.18$ & $6.71 \pm 0.19$ & - \\
\hline DM-1 & $10.19 \pm 0.03$ & $0.56 \pm 0.01$ & $1.13 \pm 0.04$ & $0.53 \pm 0.07$ & $2.03 \pm 0.14$ & $5.95 \pm 0.10$ & - \\
\hline DM-2 & $10.02 \pm 0.14$ & $0.79 \pm 0.008$ & $0.01 \pm 0.00$ & $1.15 \pm 0.03$ & $1.73 \pm 0.15$ & $6.34 \pm 0.14$ & - \\
\hline SNDM & $30.05 \pm 0.08$ & $0.59 \pm 0.03$ & $0.78 \pm 0.06$ & $2.63 \pm 0.18$ & $1.84 \pm 0.20$ & $19.21 \pm 0.13$ & - \\
\hline
\end{tabular}

Lost $\mathrm{N}=($ Initial $N-$ Final $N) /$ Initial $N \times 100 \%$.

Values were expressed as average \pm standard deviation

\section{Figures}

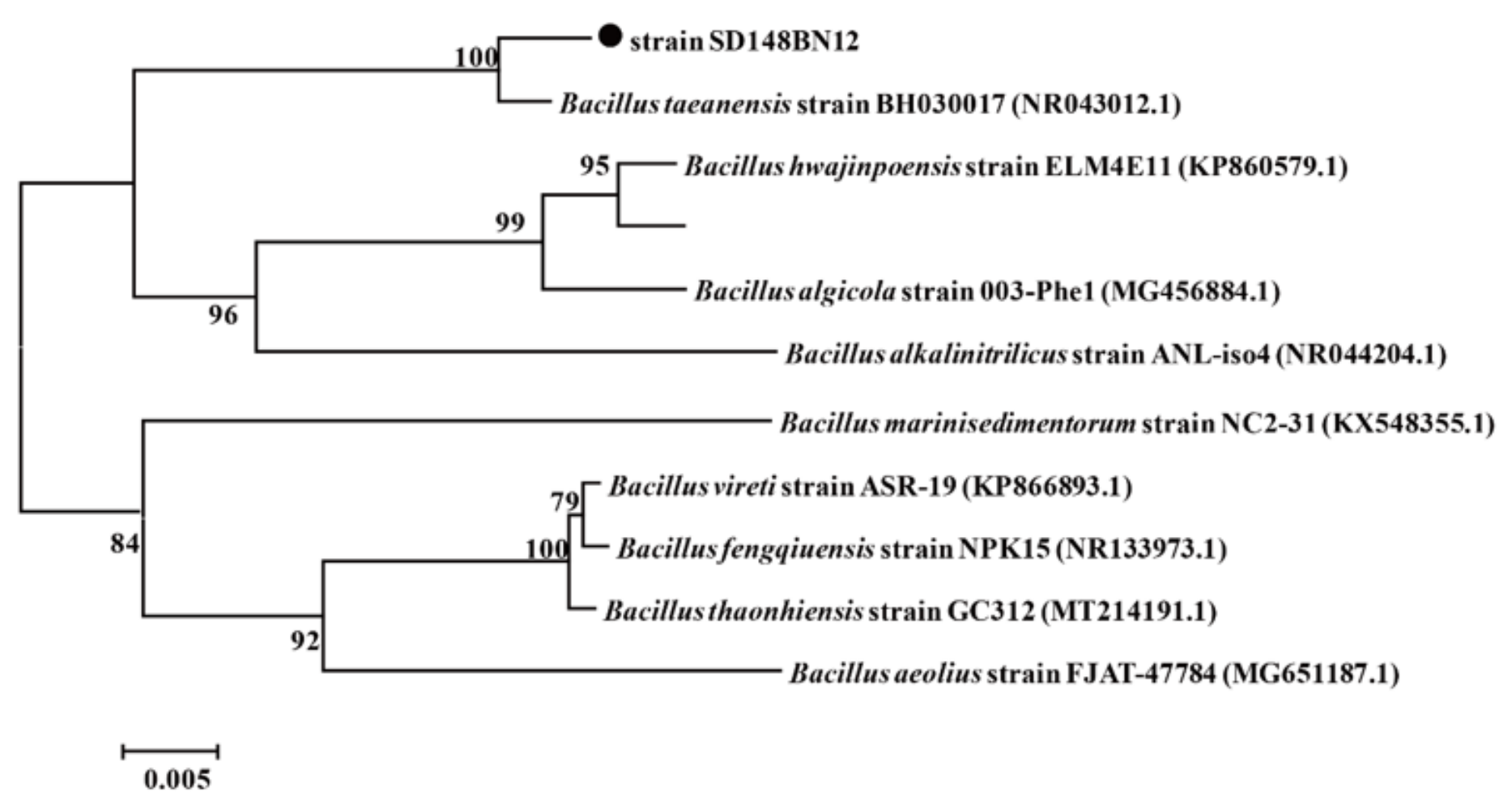

Figure 1

Phylogenetic tree based on the partial 16S rRNA gene sequences of Bacillus taeanensis SD148BN12 using neighbor-joining method with bootstrap values of 1000 replications. 


\section{Figure 2}

Nitrogen removal performance and cell growth of Bacillus taeanensis SD148BN12 under different nitrogen sources: (a) $\mathrm{NH}_{4}{ }^{+}-\mathrm{N}$ as the single nitrogen source; (b) $\mathrm{NO}_{2}{ }^{-} \mathrm{N}$ as the single nitrogen source; (c) $\mathrm{NO}_{3}{ }^{-} \mathrm{N}$ as the single nitrogen source; (d) $\mathrm{NH}_{4}{ }^{+}-\mathrm{N}, \mathrm{NO}_{2}{ }^{-}-\mathrm{N}, \mathrm{NO}_{3}{ }^{-} \mathrm{N}$ as mixed nitrogen source.

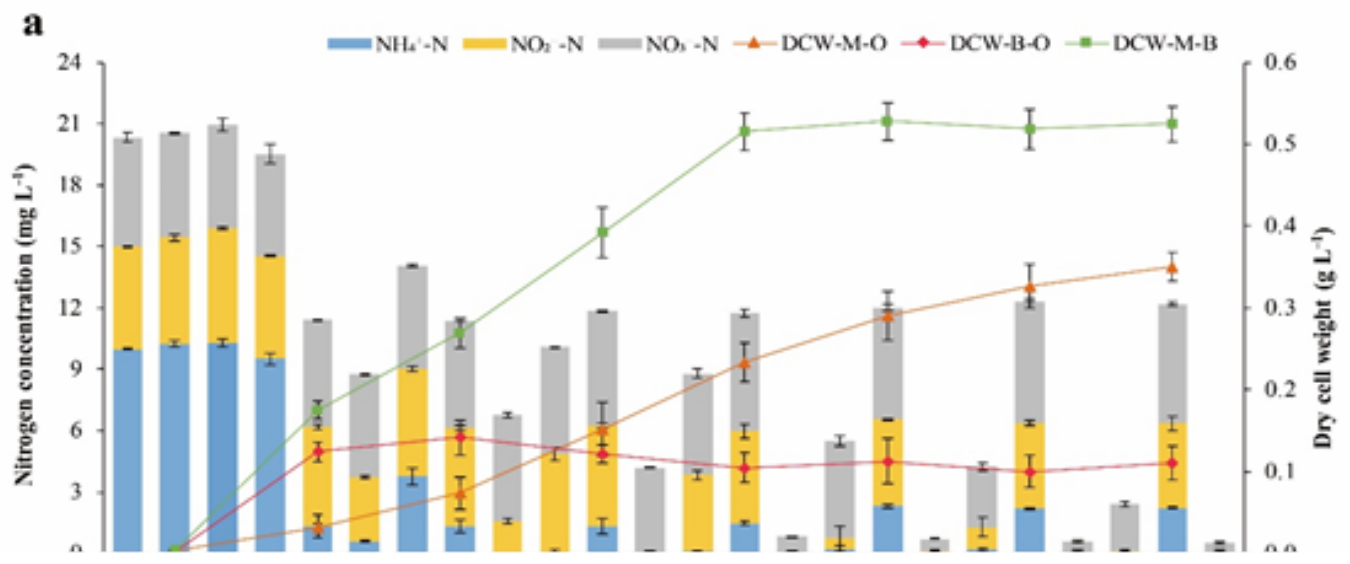

\section{Figure 3}

Nitrogen and phosphorus removal performance, biomass accumulation, and other water quality parameters of the Chlorella sp.-only (M-0), the Bacillus taeanensis SD148BN12-only (B-0), the Chlorella sp.-Bacillus taeanensis SD148BN12 consortium (M-B) in synthetic wastewater medium: (a) content of $\mathrm{NH}_{4}{ }^{+}-\mathrm{N}, \mathrm{NO}_{2}{ }^{-}-\mathrm{N}^{-} \mathrm{NO}_{3}{ }^{-} \mathrm{N}$ and dry cell weight (DCW); (b) content of TN; (c) content of TP; (d) content of dissolved oxygen; (e) pH value. 


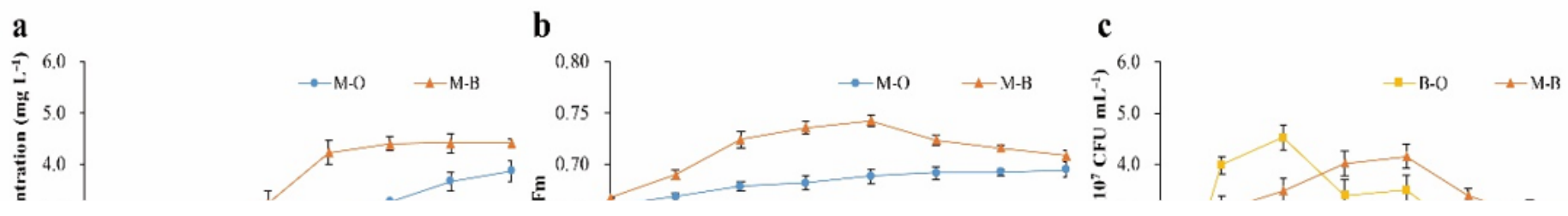

Figure 4

Microorganism growth and photosynthetic activity of the Chlorella sp.-only (M-O), the Bacillus taeanensis SD148BN12-only (B-O), the Chlorella sp.-Bacillus taeanensis SD148BN12 consortium (M-B) in synthetic wastewater medium: (a) content of Chlorophyll-a; (b) maximal photochemical efficiency (Fv/Fm); (c) number of viable bacteria.

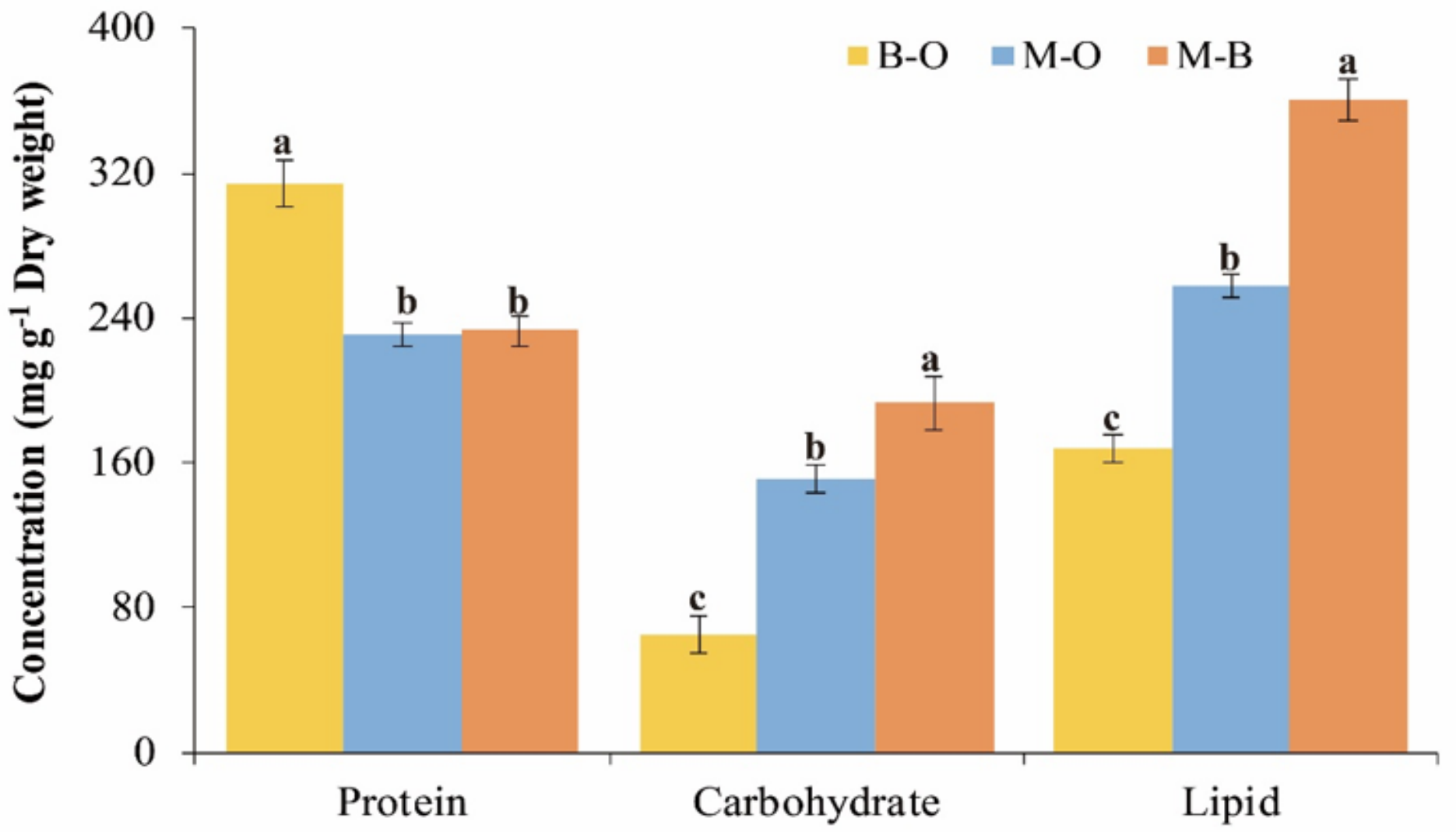

Figure 5

Biomass composition contents of the Chlorella sp.-only (M-O), the Bacillus taeanensis SD148BN12-only (B-0), the Chlorella sp.-Bacillus taeanensis SD148BN12 consortium (M-B) in synthetic wastewater medium after 14 days of cultivation. 


\section{Figure 6}

$\mathrm{TN}, \mathrm{NH}_{4}{ }^{+}-\mathrm{N}, \mathrm{NO}_{2}{ }^{-}-\mathrm{N}$ removal efficiency and dry cell weight (DCW) of the Chlorella sp.-Bacillus taeanensis SD148BN12 consortium (M-B) under different culture conditions after 8 days of cultivation: (a) temperature; (b) salinity; (c) $\mathrm{pH}$; (d) light intensity; (e) $\mathrm{C} / \mathrm{N}$ ratio; (f) N/P ratio; (g) $\mathrm{N}$ concentration.
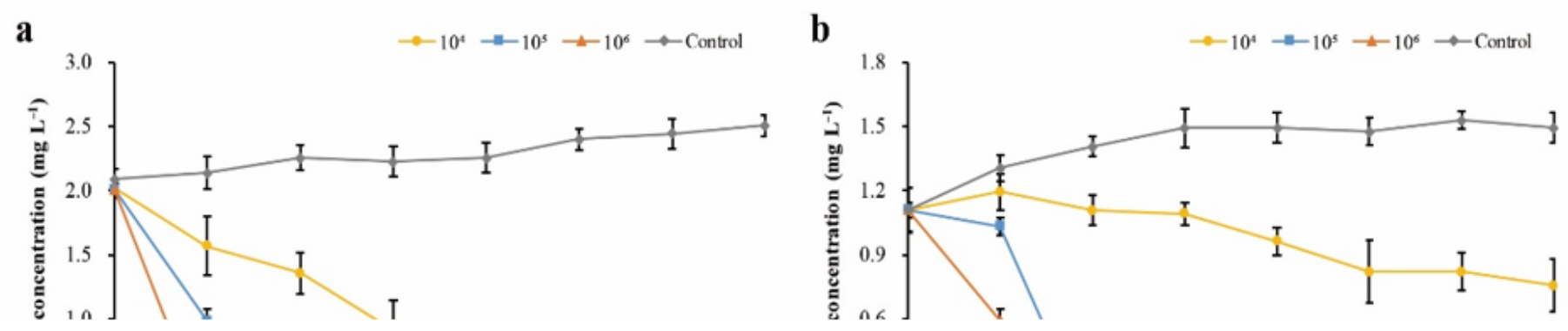

Figure 7 
The removal performance of (a) $\mathrm{NH}_{4}{ }^{+}-\mathrm{N},(b) \mathrm{NO}_{2}{ }^{-} \mathrm{N}$, (c) TN, (d) TP in mariculture water and (e) TN, (f) TP in mariculture wastewater with the inoculated density ratios of Chlorella sp. (cell/mL)-to- Bacillus taeanensis SD148BN12 (CFU/mL) as $10^{4}: 10^{4}\left(10^{4}\right), 10^{5}: 10^{5}\left(10^{5}\right), 10^{6}: 10^{6}\left(10^{6}\right)$ and 0 (control).

\section{Supplementary Files}

This is a list of supplementary files associated with this preprint. Click to download.

- Supplementarymaterials.docx 